\title{
Soil erodibility assessment in a pasture and forest remnant using the Inderbitzen device
}

\author{
A. I. Ribeiro ${ }^{1}$, L. F. Gonzalez ${ }^{1}$, R. M. Longo $^{2}$, G. A. de Medeiros ${ }^{1}$, \\ A. H. Rosa ${ }^{1}$, R. W. Lourenço ${ }^{1}$ \& F. H. Fengler ${ }^{3}$ \\ ${ }^{1}$ Universidade Estadual Paulista, UNESP, Brazil \\ ${ }^{2}$ Pontifical Catholic University of Campinas, SP, Brazil \\ ${ }^{3}$ Agronomical Institute of Campinas, IAC, Brazil
}

\begin{abstract}
Brazil has the largest cattle herd in the world with approximately 200 million head. An important feature of the Brazilian cattle industry is that most of its herd is raised on pasture, which constitutes one of the most economical and practical ways to produce and provide food for cattle. However, this production model is mishandled and can lead to soil degradation. Maintaining soil quality is essential for the conservation of natural ecosystems and the areas of production, thus soil quality improves the conditions for biogeochemical cycles. In this context, the objective of this study was to develop a device for testing the Inderbitzen way of assessing soil erodibility in two situations of usage and occupation. Therefore, one area was used as a sample collection occupied by grazing and the other as a forest fragment; both located in the city of Sorocaba in Sao Paulo State, Brazil. Thus, we concluded that the proposed device - the Inderbitzen - proved capable of assessing soil erodibility of the pasture and remnant forest. Accordingly, there was a tendency for a smaller loss of forest soils in the remnant when compared to the degraded pasture. The greatest resistance of the soil erosion in the forest remnant may be associated with the amount of organic matter released by the forest litter in all its diversity, influencing the quality of the structure of aggregates.

Keywords: erosion, forest remnant, degraded pasture, Inderbitzen test.
\end{abstract}




\section{Introduction}

Brazil has the largest cattle herd in the world with approximately 220 million head [1]. An important feature of the Brazilian cattle industry is to have most of their herd raised on pasture [2] which constitutes one of the most economical and practical way to produce and provide food for cattle. However, this production model is mishandled and can lead to soil degradation. Several authors have pointed to a degradation of Brazilian pastures, with estimates ranging from 20 to 40 million hectares $[3,4]$.

Maintaining soil quality is essential for the conservation of natural ecosystems and the areas of production, thus soil quality improves the conditions for biogeochemical cycles. The characteristics of the soil under natural vegetation, climate and in any region on any type of rock depends on the balance between accumulation processes and forces that degrade and remove the soil [5]. The biogeochemical cycles are the ways in which the nutrients essential to life circulate in the biosphere. Most of the elements and compounds are more closely linked to the ground than to air and water. Thus, the maintenance of soil quality is of fundamental importance for the conservation of ecosystems.

The vegetation cover protects the soil in order to reduce the potential energy that the raindrop produces on hitting the soil absorbing part of this energy by the vegetal canopy. This way, the roots connect the ground, maintaining their structure and the falling leaves add organic matter. The big problem is that when the cover is removed, the soil is unprotected facilitating the action of erosion, until the canopy is again formed [5].

The geological erosion is a process which naturally occurs by the action of weathering agents such as water, wind and ice, in which soil is removed from its natural state, being transported to other locations in order to deposit this sediment on places of little slope and small elevation, such as depressions and water streams. However, lately almost every process of erosion is accelerated with strong anthropogenic influence [6].

The soil compaction by animal trampling, exacerbated by the removal of vegetation caused by excessive grazing may decrease the rate of water infiltration into the soil profile by increasing erosion, thus strongly degrading the activity of livestock production. In tropical regions the pluvial erosion is the one that causes harmful effects mainly in uncovered soils. Thus the areas of livestock production suffer soil loss due to pluvial rain in compacted soil resulting in significant environmental impact. The raindrops directly splashed over the soil destabilize soil aggregates and consequently move the sediments to the alluvial areas.

To measure the erosion there are several methods in the literature, which are provided as empirical statements. The Inderbitzen test is the most commonly used means of erodibility evaluation for geotechnical soil. The test consists of a flume in which the soil sample coincides with the inclination of the channel where soil losses, caused by the laminar flow of water with controlled flow, are measured [10]. 
In this context, the objective of this study was to develop a device for testing Inderbitzen way of assessing soil erodibility in two situations of use and occupation: a remnant forest and degraded pasture.

\section{Materials and methods}

The Inderbitzen device was built using a chute PVC (Polyvinyl Chloride), wood, flow regulator (Dwyer rotameter brand - LFMB), hose, and a collector of ground steel. The trough was glued on top of the wood piece to thereby decrease the effect of bowing that occurs in PVC materials. Below the piece of wood was screwed, another piece of wood to support the specimen. At one end was added a box made of PVC $(8 \mathrm{~mm})$, to receive the load of water and overflow creating laminar flow [12].

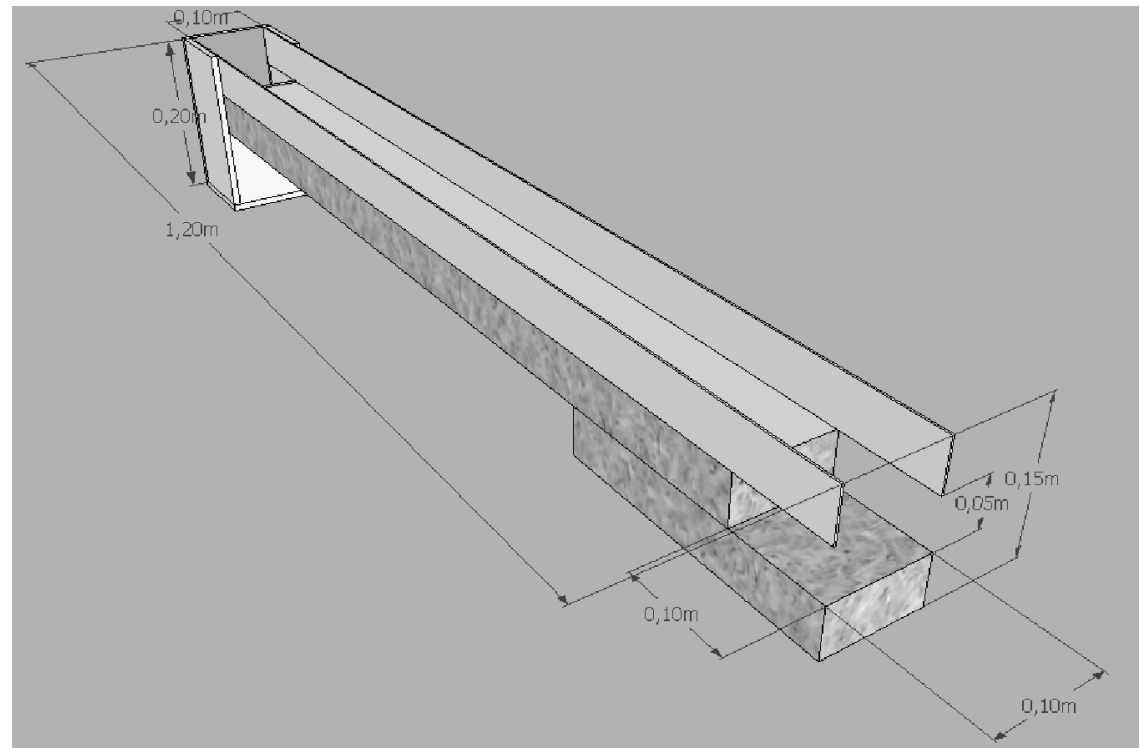

Figure 1: Dimensions (meters) of the Inderbitzen device built to perform this work.

To collect the sample, we used the method presented by [11] using a cubic soil sampler, withdrew an undisturbed sample and soon after it was wrapped in plastic wrap so that there was no loss of soil moisture. After collecting samples the test occurred with at most one day apart.

The test was performed under laminar flow, this characteristic is important for standardization of the assay. To achieve laminar flow, the Reynolds number should be less than 500 in a flow channel open. Based on this, we chose to use an inclination of $10^{\circ}$ performing the calculation of the flow according to the information provided by [13]. 
The site chosen for the collection of soil was in the municipality of Sorocaba/SP- Brazil. Sampling occurred in the same soil in a degraded pasture and remnant forest. The geographical coordinates are $23^{\circ} 27^{\prime} 05.89^{\prime \prime} \mathrm{S}$ and $47^{\circ} 25^{\prime}$ $31.26 \mathrm{"} \mathrm{W}$ an area of $608 \mathrm{~m}$ above sea level. The test was done for 3 soil samples from the remaining forests and 3 samples for grazing. According to the Center for Research in Weather and Climate Applied to Agriculture, from University of Campinas, the climate of Sorocaba is Cwa, i.e. humid temperate climate with dry winters and summers [12]. The experimental area was classified as Oxisol, based on particle size analysis, held at $0-0.20 \mathrm{~m}$ layer, it appears that average levels of $350 \mathrm{~g} \mathrm{~kg}^{-1}$ sand, $61 \mathrm{~g} \mathrm{~kg}^{-1}$ silt and $589 \mathrm{~g} \mathrm{~kg}^{-1}$ clay [13]. To collect samples for the test, we used a sampler format parallelepiped dimensions: 10x $10 \times 5 \mathrm{~cm}$ and larger hollow cheeks.

\section{Results and discussion}

The device is constructed as shown in Figure 2.

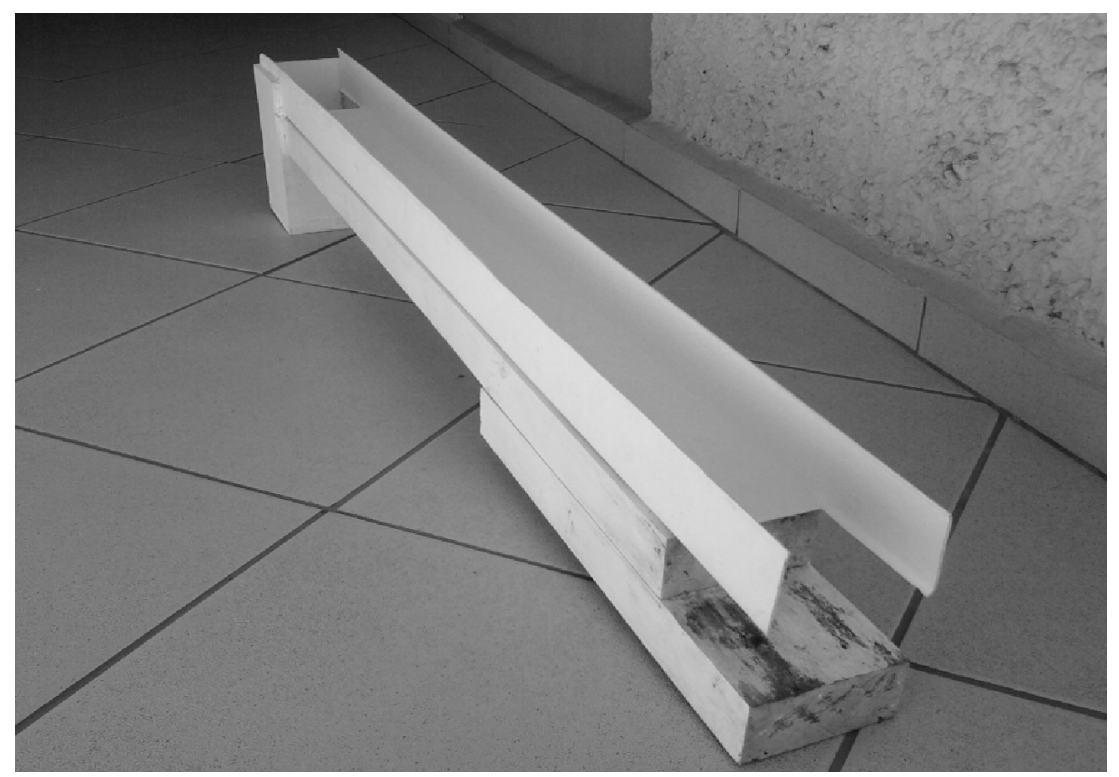

Figure 2: $\quad$ Constructed Inderbitzen device.

Table 1 shows different tendencies among the samples, and in sample 5 , there is a greater loss of soil value than the other samples. This condition may be associated with a greater or lower amount of roots in the sample, because the roots act as retainers of soil particles, causing a greater resistance to laminar flow

Data generated by the test on soil degraded pasture are shown in Table 2.

As in the remnant forest there was a sample that showed much higher values of soil loss. This fact may also be associated to the presence of roots, mainly 
Table 1: $\quad$ Data from the test soils for Inderbitzen forest remnant.

\begin{tabular}{|c|c|c|c|c|c|c|c|c|}
\hline \multicolumn{9}{|c|}{ FOREST REMNANT } \\
\hline
\end{tabular}

Table 2: $\quad$ Data from the Inderbitzen test for soils degraded pasture.

\begin{tabular}{|c|c|c|c|c|c|c|c|c|}
\hline \multirow[b]{3}{*}{$\begin{array}{l}\text { Time } \\
\text { (min) }\end{array}$} & \multicolumn{8}{|c|}{ DEGRADED PASTURE } \\
\hline & \multicolumn{2}{|c|}{ Sample 2} & \multicolumn{2}{|c|}{ Sample 4} & \multicolumn{2}{|c|}{ Sample 6} & \multirow[b]{2}{*}{$\begin{array}{l}\text { Average } \\
\text { cumulative } \\
\text { loss of soil } \\
\left(\mathrm{g} / \mathrm{cm}^{2}\right)- \\
\text { Dry Weight } \\
\end{array}$} & \multirow[b]{2}{*}{$\begin{array}{c}\text { Standard } \\
\text { deviation of } \\
\text { accumulated } \\
\text { soil loss } \\
\end{array}$} \\
\hline & $\begin{array}{c}\text { Sample } \\
\text { weight (g) }\end{array}$ & \begin{tabular}{|c|} 
Loss of soil \\
accumulated \\
$\left(\mathrm{g} / \mathrm{cm}^{2}\right)-$ \\
Base Dry \\
Sample \\
\end{tabular} & $\begin{array}{c}\text { Sample } \\
\text { weight (g) }\end{array}$ & $\begin{array}{c}\text { Loss of soil } \\
\text { accumulated } \\
\left(\mathrm{g} / \mathrm{cm}^{2}\right)- \\
\text { Base Dry } \\
\text { Sample } \\
\end{array}$ & $\begin{array}{l}\text { Standard } \\
\text { deviation of } \\
\text { accumulated } \\
\text { soil loss }\end{array}$ & \begin{tabular}{|c|}
$\begin{array}{c}\text { Loss of soil } \\
\text { accumulated } \\
\left(\mathrm{g} / \mathrm{cm}^{2}\right)- \\
\text { Base Dry } \\
\text { Sample Base } \\
\text { Dry }\end{array}$ \\
\end{tabular} & & \\
\hline 0 & 382,81 & 0,00 & 275,39 & 0,00 & 295,57 & 0,000 & 0,000 & 0,000 \\
\hline 1 & 365,20 & 0,18 & 239,98 & 0,35 & 283,06 & 0,125 & 0,218 & 0,120 \\
\hline 5 & 360,60 & 0,22 & 222,14 & 0,53 & 280,14 & 0,154 & 0,303 & 0,202 \\
\hline 10 & 356,96 & 0,26 & 212,30 & 0,63 & 277,57 & 0,180 & 0,356 & 0,241 \\
\hline 15 & 356,07 & 0,27 & 203,30 & 0,72 & 277,14 & 0,184 & 0,391 & 0,289 \\
\hline 20 & 355,25 & 0,28 & 198,59 & 0,77 & 276,78 & 0,188 & 0,411 & 0,313 \\
\hline
\end{tabular}

because the area is dotted with bare soil. Another factor that may have generated this clear distinction between samples from the same area is the existence of a greater amount of disaggregated sand on the site which would generate greater soil loss.

Table 3 shows the values of the cumulative loss of soil corresponding to the time of 20 minutes. As Table 3 shows the t-test ( $5 \%$ level), there is no significant difference among the values, in the soil loss in both areas. This may be due to the 
small number of samples collected. Thus, it is observed that the device proved to be an effective tool to check resistance of soils to erosion by laminar flow. The influence of chemical and physical conditions of the soil as organic matter, CEC (Cation Exchange Capacity), porosity and void index were crucial to assess the trend of vulnerability that each soil possessed, even the two soils being characterized as red Oxisoil and not presenting significant differences at loss of soil.

The values of soil loss found in Inderbitzen test ranged from $0.08 \mathrm{~g} / \mathrm{cm}^{2}$ to $0.78 \mathrm{~g} / \mathrm{cm}^{2}$ [10]. In another study it was observed erodibility values for RedYellow Podzolic soils ranging from 0.002 to $0.61 \mathrm{~g} / \mathrm{cm}^{2}$, and this type of soil possesses about 50\% clay, similar to that found in soil sampled in this study [10]. The values obtained in the pasture and the remainder were within these ranges.

Table 3: $\quad$ Soil loss [\%] in the different use and occupation.

\begin{tabular}{|c|c|c|c|c|c|}
\hline & $\begin{array}{c}\text { Sample } 1 \\
(\%)\end{array}$ & $\begin{array}{c}\text { Sample } \\
2(\%)\end{array}$ & $\begin{array}{c}\text { Sample } 3 \\
(\%)\end{array}$ & \multirow{3}{*}{$\begin{array}{c}\text { Average } \\
\text { deviation of } \\
\text { differences }\end{array}$} & \multirow{3}{*}{$\begin{array}{c}\text { Standard } \\
\text { deviation of } \\
\text { the differences }\end{array}$} \\
\hline Forestry & 7 & 9 & 9,4 & & \\
\hline $\begin{array}{c}\text { Degraded } \\
\text { pasture }\end{array}$ & 28 & 77 & 18,8 & & \\
\hline $\begin{array}{c}\text { Difference } \\
\text { between the } \\
\text { porosities }\end{array}$ & 21 & 68 & 9,4 & 32,8 & 31,03 \\
\hline $\begin{array}{l}\mathrm{tcal}=1,8 ; \\
\mathrm{t} t a b=4,31 ;\end{array}$ & & & & $5 \%$ (not si & cant). \\
\hline
\end{tabular}

\section{Conclusion}

According to the methodology used and the results obtained, it can be concluded that the device was capable of evaluating the erodibility of soils in different usage scenarios and occupation.

The applied statistics were not significant; this may be associated with the small number of samples for data analysis which show a strong trend of reduced soil loss compared to the remaining in the degraded pasture, providing a 
methodology to evaluate environmental impact of the change of vegetative cover in subtropical mesological conditions.

The trend of increased resistance to soil erosion in forest remnant may be associated with the amount of organic matter release by the forest litter in all its diversity. This observation reinforces the importance of maintaining forest remnants in urban and rural areas as a way to preserve soil quality, which is very vulnerable under conditions of sparse vegetation in areas of Brazilian degraded pasture.

\section{References}

[1] IBGE (Instituto Brasileiro de Geografia e Estatística). Statistics onlivestock.Availableon:http://www.ibge.gov.br/home/download/estatistica .shtm Access on March 6, 2012.

[2] Ferraz, J. B. S. and Felício, P. E. D. Production systems - an example from Brazil. Science, v. 84, n. 2, p. 238-243, 2010.

[3] Batistella, M., Andrade, R. G. and Bolfe, E. L. Geotechnologies and territorial management of Brazilian cattle. Revista Brasileira de Zootecnia, 40(SE), pp. 251-260, 2011 (in Portuguese).

[4] Peron, A. J. and Evangelista, A. R. Pasture degradation in savanna’s regions. Ciência e Agrotecnologia, 28(3), pp. 655-661, 2004 (in Portuguese).

[5] Townsend, C. R., Begon, M. and Harper, J. L. Fundamentos em Ecologia. Porto Alegre: Artmed, 2006.

[6] Bertoni, J. and Neto, F. L. Conservação do Solo. $5^{\circ}$ Edição, São Paulo: Ícone, 2005.

[7] Oliveira, A. M. S. and Brito, S. N. A. (Ed.) Geologia de Engenharia. São Paulo: Associação Brasileira de Geologia de Engenharia, 1998.

[8] Filho, C. L. M. Introdução à Geologia de Engenharia. $2^{\circ}$ Edição, Santa Maria: Editora da UFSM; Brasília: Companhia de Pesquisas de Recursos Minerais, 1997.

[9] Mafra, N. M. C. Erosão e Planificação de Uso do Solo. In: Guerra, A. J. T., Silva, A. S., Botelho, R. G. M. (Org.). Erosão e Conservação dos Solos. $2^{\circ}$ Edição. Rio de Janeiro: Bertrand Brasil, 2005.

[10] Bastos, C. A. B., Milititsky, J. and Gehling, W. A Avaliação da erodibilidade dos Solos sob o enfoque Geotécnico - Pesquisa e Tendências. Teoria e Prática na Engenharia Civil, No. 1, p. 17-25, Nov., 2000.

[11] Aguiar, V. G. and Romão, P. A. Proposta de mensuração de erodibilidade do solo em laboratório. In: XI Simpósio Regional de Geografia, 2009, Campus Jataí. GO.

[12] Rolim, G. S., Camargo, M. B. P., Lania, D. G., Moraes, J. F. L. Classificação Climática de Köppen e de Thornthwaite e sua Aplicabilidade na determinação de Zonas agroclimáticas para o Estado de São Paulo. Bragantia, Campinas, v.66, n.4, p. 711-720, 2007.

[13] Empresa Brasileria de Pesquisa Agropecuaria: Meio Ambiente. Disponível em: <http://www.cnpma.embrapa.br/analise_econ/>. Acesso em: 25 de Outubro de 2011. 